\title{
In silico analysis of antihypertensive and hepatotoxicity potential of the n-butanol fraction of the methanol extract of of cantaloupe (Cucumis melo var. cantalupensis)
}

DOI: https:// doi.org/10.22435/hsji.v11i2.3629

Dian Laila Purwaningroom ${ }^{1}$, Dianita Rifqia Putri ${ }^{1}$, Galuh Wening Permatasari ${ }^{2}$
${ }^{1}$ Faculty of Health Sciences, Universitas Muhammadiyah Ponorogo, Jawa Timur, Indonesia
${ }^{2}$ Indonesian Research Institute for Biotechnology and Bioindustry (IRIBB), Bogor, Indonesia

Corresponding author: Dian Laila Purwaningroom

Email: dianlaila@umpo.ac.id

Received: June 4, 2020; Revised: November 10, 2020; Accepted: December 7, 2020

\begin{abstract}
Abstrak
Latar belakang: Hipertensi merupakan faktor risiko utama penyakit kardiovaskular. Penduduk Indonesia cenderung mengkonsumsi herbal dalam terapi hipertensi dalam mempertahankan kadar tekanan darah seperti buah blewah (Cucumis melo var. cantalupensis). Namun mekanisme kerja buah blewah dalam menurunkan tekanan darah, dan potensi toksisitasnya jika dikonsumsi dalam jangka panjang masih belum jelas. Tujuan studi ini adalah untuk menganalisis mekanisme antihipertensi dari buah blewah dan potensi toksiknya melalui pendekatan in silico.

Metode: Bubuk blewah kering dimaserasi menggunakan metanol absolut, difraksinasi menggunakan n-butanol. Uji fitokimia dilakukan dengan metode LC-MS, kemudian senyawa bioaktif ditelusuri hingga SMILESnya di PubChem. Analisis QSAR untuk analisis potensi antihipertensi dilakukan dengan PASS server. Kelas toksisitas dan potensi hepatotoksisitas dianalisis menggunakan ProTox-II, dilanjutkan dengan analisis networking menggunakan STITCH dan STRINGdb.

Hasil: Setidaknya terdapat 434 jenis senyawa yang terdapat pada fraksi n-butanol dari ekstrak metanol buah blewah (FBEMB). Berdasarkan analisis STITCH dan STRINGdb, FBEMB dapat bekerja dalam menurunkan tekanan darah melalui mekanisme aksi seperti senyawa amlodipine, yang menstabilkan saluran kalsium tipe-L yang terisi tegangan dalam konformasi tidak aktifnya. Dengan demikian, mencegah kontraksi myocyte yang bergantung pada kalsium dan vasokonstriksi. FBEMB mungkin berpotensi hepatotoksik melalui mekanisme kerja senyawa seperti itrakonazol yang menghambat enzim sitokrom P450 yang mempengaruhi gangguan pada sintesis ergosterol, dan efavirenz yang memiliki efek neurotoksik. Penghambatan sitokrom P450 dapat menyebabkan toksisitas obat dan kerusakan hati.
\end{abstract}

Kesimpulan: FBEMB dapat bekerja dalam menurunkan tekanan darah melalui mekanisme penstabilan saluran kalsium tipe-L yang terisi tegangan dalam konformasi tidak aktifnya. (Health Science Journal of Indonesia 2020;11(2):106-14)

Kata kunci: in silico, antihipertensi, hepatotoksisitas, blewah

\begin{abstract}
Background: Hypertension is a major cardiovascular disease risk factor. Indonesian people tend to consume herbal medicine to maintain hypertension therapy, i.e cantaloupe (Cucumis melo var. cantalupensis). However, the mechanism of action of cantaloupe in lowering blood pressure and toxicity potential for long term consumption is unclear. The study aimed to analyze the antihypertensive mechanism of cantaloupe and its toxic potential through the in silico
\end{abstract}

Methods: The dried cantaloupe powder was macerated using absolute methanol, then fractionated using n-butanol. The phytochemical test was done by LC-MS method, then the bioactive compounds were traced to their SMILES in the PubChem. The QSAR analysis of the antihypertensive potential was done using the PASS server. The toxicity class and hepatotoxicity potential were analyzed using ProTox-II, followed by networking analysis using STITCH and STRINGdb.

Results: At least 434 types of compounds were shown in the n-butanol fraction of the methanol extract of cantaloupe (BFMEC). Based on the networking analysis, BFMEC may work in lowering blood pressure through the action mechanism of the amlodipine compound-like, which stabilizes voltage-gated L-type calcium channels in an inactive conformation, thus, prevents calcium-dependent myocyte contraction and vasoconstriction. BFMEC presumably has hepatotoxic through the action mechanism of itraconazole compound-like inhibited cytochrome P450-dependent enzymes, affecting the impairment of ergosterol synthesis, and efavirenz which has neurotoxic effects. The inhibition of cytochrome P450 may cause drug toxicity and liver damage.

Conclusion: BFMEC may work in lowering blood pressure through the action mechanism which stabilizes voltage-gated L-type calcium channels in an inactive conformation. (Health Science Journal of Indonesia 2020;11(2):106-14)

Keywords: in silico, antihypertensive, hepatotoxicity, cantaloupe 
Hypertension is a major risk factor in cardiovascular disease. Globally, there are about one third of people with hypertension are undiagnosed, and half of those diagnosed do not take antihypertensive drugs. ${ }^{1}$ The drug can be considered as a xenobiotic group, which are compounds originating from outside the body that enters the body. ${ }^{2}$ The liver plays an important role in the metabolism of xenobiotics, making this organ vulnerable to chemicals that are exposing ubiquitously. Most of the liver damage caused by chemicals begins with the metabolism of chemicals, such as reactive intermediates such as electrical compounds or free radicals, which can alter the structure and function of cellular cell molecules. ${ }^{3}$

Indonesian people tend to consume herbal medicine to maintain good health ${ }^{4}$ jamu is still very popular in rural as well as in urban areas. Based on its traditional use jamu is being developed into a rational form of therapy, by herbal practitioners and in the form of phytopharmaceuticals. Jamu has acquired a potential benefit, both economically and clinically. We surveyed the most frequently used plants in jamu that have also been investigated regarding their constituents and pharmacological effects. The Indonesian government has divided the preparation of medicinal plants into three categories, i.e. jamu, standardized herbal medicines and fitofarmaka (phytomedicines, including hypertension therapy. ${ }^{5}$ Cantaloupe (Cucumis melo L) is often used in hypertension therapy in Indonesia, especially among Javanese people. Some studies showed that Cucumis melo L inhibits phenylephrine-mediated vasoconstriction in mice. ${ }^{6}$ But it is not yet known the mechanism of action of cantaloupe in lowering blood pressure. It also not known the potential of toxicity if consumed in the long term.

Nowadays, the process of drug discovery which begins with the bioinformatics method is very popular. This is because the method efficiently reduce the occurrence of trials and errors during in vitro and in vivo studies. Therefore, this study aimed to analyze the antihypertensive and hepatotoxicity potential of the n-butanol fraction of the methanol extract of cantaloupe (Cucumis melo var. cantalupensis) (BFMEC) through the bioinformatics approach.

\section{METHODS}

\section{Tools and materials}

The materials used in extraction are cantaloupe fruits, methanol absolut as maceration solvent, and
n-Buthanol as fractionation solvent. Material used in Phytochemical tests were $0.1 \%$ Formic acid in Water, $0.1 \%$ Formic acid in Acetonitrile as LC-MS Solvent and Hypersil GOLD aQ 50 x $1 \mathrm{~mm}$ x $1.9 \mathrm{u}$. Tools used in maceration were analytical balance, beaker glass, wood stirrer, cloth, funnel, rotary evaporator, and extract bottle. Tools used in phtochemical test were Thermo Scientific Dionex Ultimate 3000 RSLCnano with microflow meter. The tool used for tracing the canonical SMILES was PubChem (https://pubchem. ncbi.nlm.nih.gov). Bioinformatic tools used in this study were Way2Drug (http://www.pharmaexpert. $\mathrm{ru} /$ passonline/) to analize antihypertensive potential, STITCH (http://stitch.embl.de/) to analize liganprotein interactions, STRINGdb (https://string-db. org) to analize target proteins interactions.

\section{Cantaloupe extraction and phytochemical testing}

Cantaloupe fruits we obtained in April 2018 from Materia Medica Batu, were cut and air dried for 7 days. The dried cantaloupe was crushed into powder for subsequent maceration. Extraction was carried out by maceration method. Two hundred grams of cantaloupe powder were macerated in 3 liters of absolute methanol in beaker glass for 3 days. The extract is then filtered and dried using a rotary evaporator. Fractionation is done using n-Butanol. The BFMEC stored at $4^{\circ} \mathrm{C}$ until used. Phytochemical tests were carried out by the method Liquid ChromatographyMass Spectrometry using Thermo Scientific Dionex Ultimate 3000 RSLCnano with microflow meter. Solvents: $\mathrm{A}=0.1 \%$ Formic acid in Water; $\mathrm{B}=0.1 \%$ Formic acid in Acetonitrile. Analytical column: Hypersil GOLD aQ 50 x $1 \mathrm{~mm}$ x 1.9 u particle size. Analytical flow rate: $40 \mathrm{uL} / \mathrm{min}$. Flow gradient: Run time 30 minutes; Column oven $30 \mathrm{C}$.

\section{Analysis of antihypertensive potential}

The names of the compounds contained in BFMEC from LC-MS test result are traced to the canonical SMILES via PubChem (https://pubchem.ncbi. nlm.nih.gov). BFMEC antihypertensive potential was analyzed by inputting SMILES in Way2Drug (http://www.pharmaexpert.ru/passonline/), potentially antihypertensive compounds with $\mathrm{Pa}>0.3$ were selected. The interaction of antihypertensive compounds with their predicted functional partners was analyzed using STITCH (http://stitch.embl.de/). Interactions between target proteins were analyzed using STRINGdb (https://string-db.org). 


\section{Analysis of hepatotoxicity potential}

The potential of BFMEC hepatotoxicity was analyzed by inputting SMILES on ProTox-II (http://tox.charite.de/protox_II/). In ProTox-II, the hepatotoxicity potential of each compound was indicated by "active" or "inactive" information along with the probability of hepatotoxicity score. We chose compounds that fell into the "active" category. Interactions of antihypertensive compounds with predicted functional partners were analyzed using STITCH. Interactions between target proteins were analyzed using STRINGdb.

\section{Ethical clearance}

This research doesn't require ethical clearance due to the absence of human involvement as research subjects.

\section{RESULTS}

\section{Cantaloupe extraction and phytochemical testing}

Extraction carried out by maceration with methanol solvent on 200 grams of cantaloupe powder simplicia produced 16.03 grams of crude extract and 2.214 grams of n-butanol fraction. Phytochemical tests were carried out using the LC-MS method, showed that there were 434 types of bioactive compounds (Figure 1).

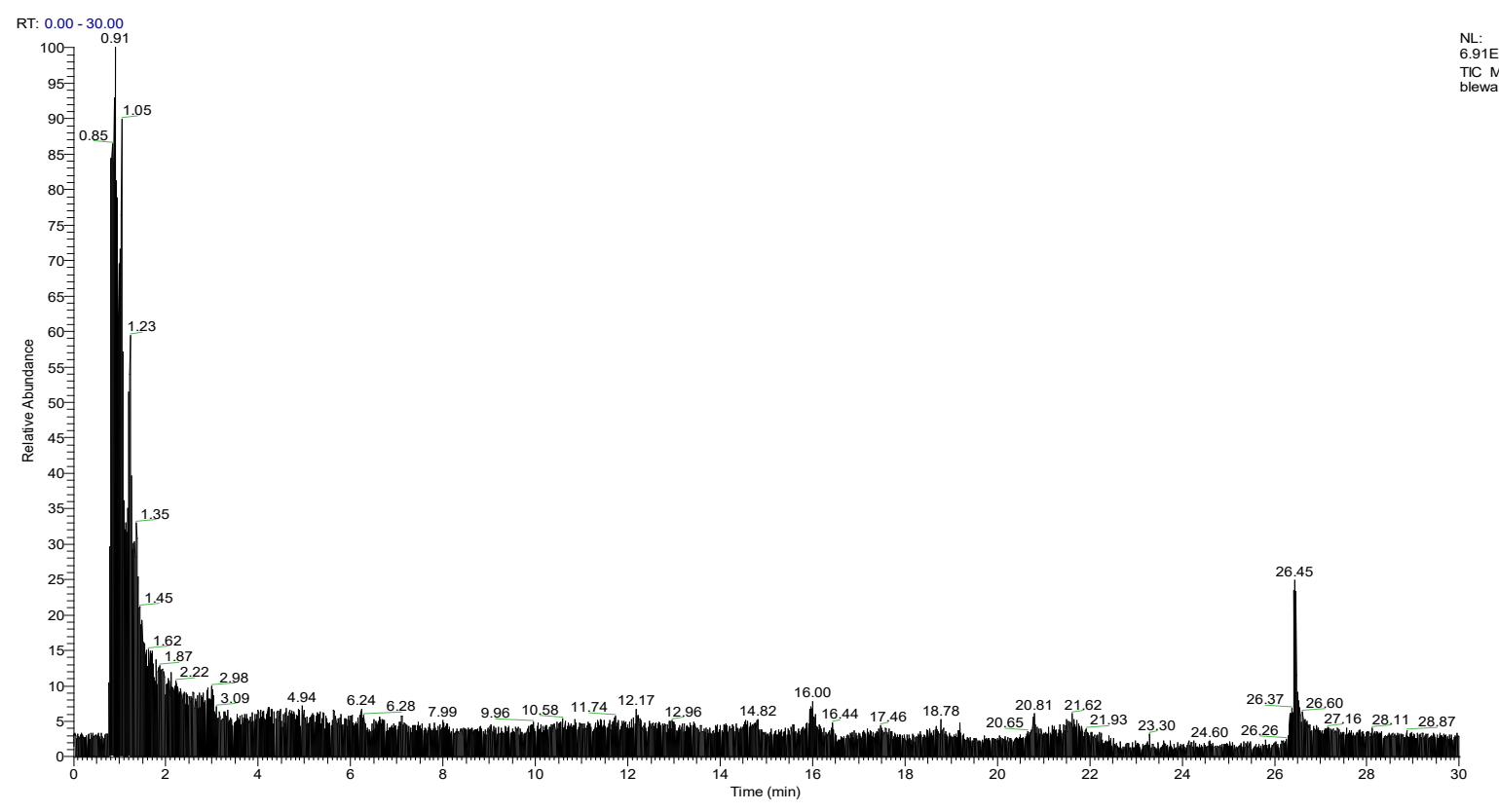

Figure 1. Chromatogram of the n-butanol fraction of the methanol extract of cantaloupe (Cucumis melo var. cantalupensis) (BFMEC) phytochemical testing using LC-MS method

We traced to the canonical SMILES via of the 434 bioactive compounds via PubChem (https:// pubchem.ncbi.nlm.nih.gov). With these canonical SMILES we traced their antihypertensive potential. BFMEC antihypertensive potential was analyzed by inputting the canonical SMILES of 434 bioactive compounds in Way2Drug (http://www.pharmaexpert. $\mathrm{ru} /$ passonline/), potentially antihypertensive compounds with $\mathrm{Pa}>0.3$ were selected.

\section{Analysis of antihypertensive potential}

Based on the results of the analysis of antihypertensive potential on Way2Drug, there were 24 compounds that had the potential as antihypertensive drugs in BFMEC marked with a value of $\mathrm{Pa}>0.3$ (data not shown). However, only 3 compounds (Table 1 ) that displayed direct interaction with the target proteins (Table 2); amlodipine (2162), okadaic acid (446512), and terfenadine (5405), respectively.

Table 1. The active compound in the BFMEC with the anti-hypertensive potential

\begin{tabular}{llcc}
\hline No & \multicolumn{1}{c}{ Name } & $\begin{array}{c}\text { Compound } \\
\text { ID }\end{array}$ & $\begin{array}{c}\text { Pa score of } \\
\text { antihypertensive }\end{array}$ \\
\hline 1 & $\begin{array}{l}\text { [Similar to: Amlodipine; } \\
\Delta \text { Mass: } 92.0960 \mathrm{Da}]\end{array}$ & $\underline{2162}$ & 0,917 \\
2. & $\begin{array}{l}\text { [Similar to: Okadaic } \\
\text { acid; } \Delta \text { Mass: } 540.3353\end{array}$ & $\underline{446512}$ & 0,459 \\
& $\begin{array}{l}\text { Da] } \\
\text { [Similar to: Terfenadine; }\end{array}$ & $\underline{5405}$ & 0,329 \\
\hline & $\Delta$ Mass: $-18.0060 \mathrm{Da}]$
\end{tabular}



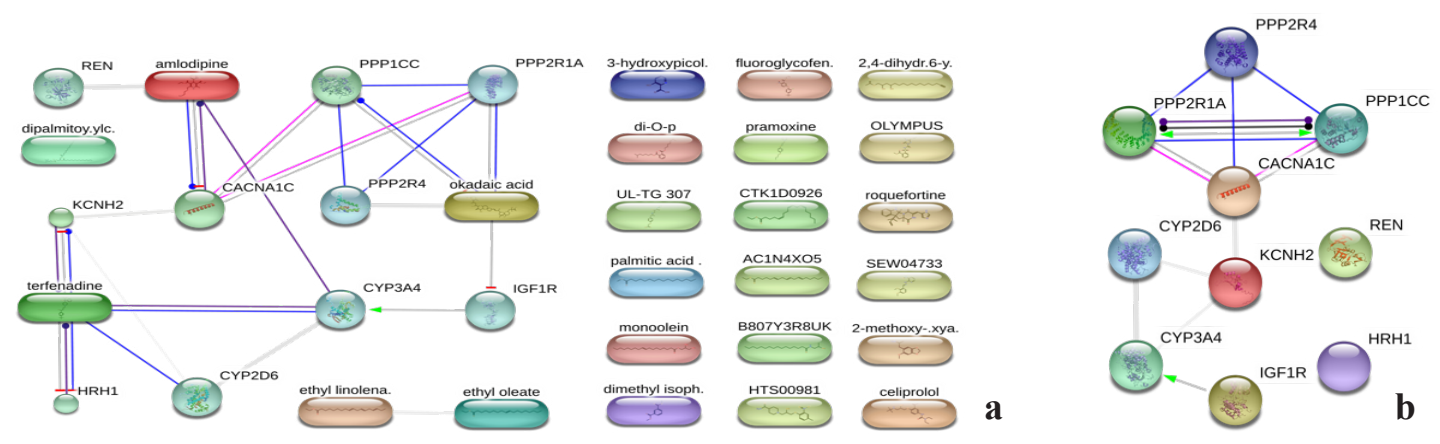

Figure 2a. Interactions of the active compounds in the BFMEC with the antihypertensive potential.

$2 b$. Interactions between predicted functional partners of the active compound in the BFMEC with the antihypertensive potential

Table 2 showed predicted functional partners of the active compound in the BFMEC with the potential of antihypertensive. Figure $2 b$ showed the interaction between proteins that were targeted by BFMEC compounds. There were interrelated interactions between PPP2R1A, PPP2R4, PPP1CC, and CACNA1C. PPP2R1A, PPP2R4, and PPP1CC are a group of protein phosphatase. IGF1R showed positive interaction with CYP3A4. REN and HRH1 didn't show any interaction with other target proteins. In this predicted functional partners showed that $\mathrm{KCNH} 2$ interacted with CACNA1C, CYP2D6, and CYP3A4.

Table 2. Predicted functional partners of the active compound in the BFMEC with the antihypertensive potential

\begin{tabular}{|c|c|c|c|c|c|c|c|}
\hline \multirow{2}{*}{ No } & \multirow{2}{*}{\multicolumn{2}{|c|}{ Protein Name }} & \multicolumn{4}{|c|}{ Action } & \multirow[t]{2}{*}{ Score } \\
\hline & & & Activation & Inhibition & Binding & & \\
\hline 1. & $\mathrm{KCNH} 2$ & $\begin{array}{l}\text { potassium voltage-gated channel, subfamily } \mathrm{H} \text { (eag- } \\
\text { related), member } 2\end{array}$ & & $\mathrm{~V}$ & $\mathrm{~V}$ & $\mathrm{~V}$ & 0,997 \\
\hline 2. & CACNA1C & $\begin{array}{l}\text { calcium channel, voltage-dependent, L type, alpha 1C } \\
\text { subunit }\end{array}$ & & $\mathrm{V}$ & $\mathrm{V}$ & $\mathrm{V}$ & 0,995 \\
\hline 3. & PPP1CC & $\begin{array}{l}\text { protein phosphatase } 1 \text {, catalytic subunit, gamma } \\
\text { isozyme }\end{array}$ & & $\mathrm{V}$ & $\mathrm{V}$ & & 0,993 \\
\hline 4. & HRH1 & histamine receptor $\mathrm{H} 1$ & & $\mathrm{~V}$ & $\mathrm{~V}$ & $\mathrm{~V}$ & 0,991 \\
\hline 5. & REN & renin & $\mathrm{V}$ & & & & 0,991 \\
\hline 6. & CYP2D6 & cytochrome P450, family 2, subfamily D, polypeptide 6 & & $\mathrm{~V}$ & $\mathrm{~V}$ & & 0,984 \\
\hline 7. & IGF1R & insulin-like growth factor 1 receptor & & $\mathrm{V}$ & & & 0,975 \\
\hline 8. & CYP3A4 & cytochrome P450, family 3 , subfamily A, polypeptide 4 & & & V & $\mathrm{V}$ & 0,968 \\
\hline 9. & PPP2R1A & protein phosphatase 2 , regulatory subunit $\mathrm{A}$, alpha & & $\mathrm{V}$ & $\mathrm{V}$ & & 0,963 \\
\hline 10. & PPP2R4 & protein phosphatase $2 \mathrm{~A}$ activator, regulatory subunit 4 & & $\mathrm{~V}$ & & & 0,959 \\
\hline
\end{tabular}

\section{Analysis of hepatotoxicity potential}

Based on the results of the analysis of hepatotoxicity potential on ProTox-II, there were 10 compounds in the BFMEC that showed hepatotoxic activity with $\mathrm{Pa}>0.3$ (data not shown). However, there were only 2 compounds that interacted directly with the target proteins; itraconazole (3793) and efavirenz (64139), mentioned below in the table 3 .
Table 3. The active compound in the BFMEC with the hepatotoxicity potential

\begin{tabular}{clcc}
\hline No & \multicolumn{1}{c}{ Name } & $\begin{array}{c}\text { Compound } \\
\text { ID }\end{array}$ & $\begin{array}{c}\text { Probability of } \\
\text { hepatotoxicity }\end{array}$ \\
\hline 1. & $\begin{array}{l}\text { [Similar to: } \\
\text { Itraconazole; } \Delta \text { Mass: } \\
\text { 370.0933 Da] }\end{array}$ & $\underline{3793}$ & 0.88 \\
\hline 2. & $\begin{array}{l}\text { [Similar to: Efavirenz; } \\
\Delta \text { Mass: } 112.9863 \mathrm{Da}]\end{array}$ & $\underline{64139}$ & 0.83 \\
\hline
\end{tabular}




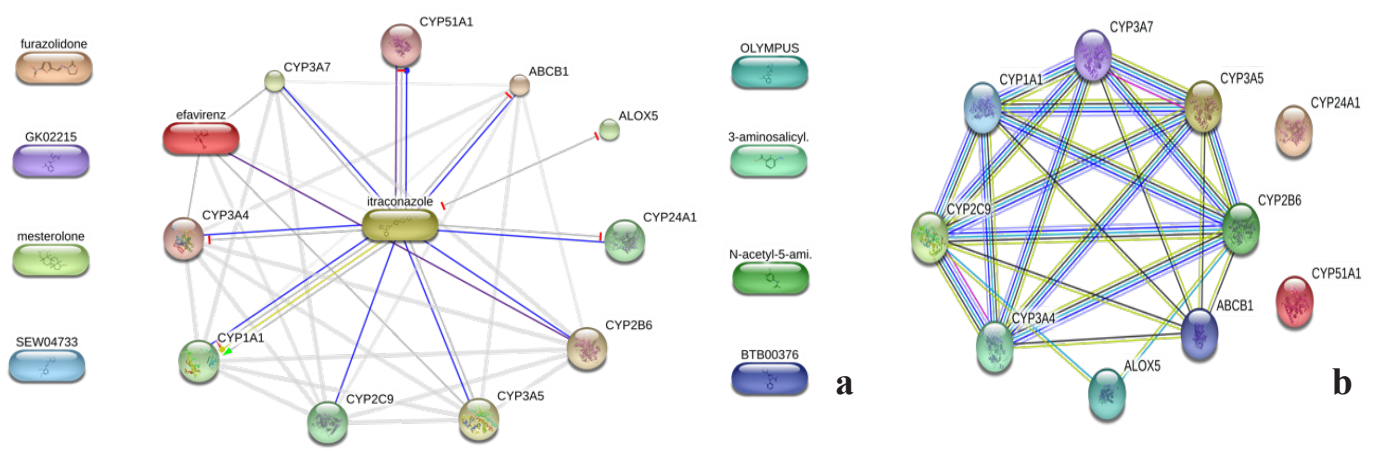

Figure 3a. Interactions of the active compound in the BFMEC with the hepatotoxicity potential.

3b. Interactions between predicted functional partners of the active compound in the BFMEC with the hepatotoxicity potential

Table 4. Predicted functional partners of the active compound in the BFMEC with the hepatotoxicity potential

\begin{tabular}{|c|c|c|c|c|c|c|c|}
\hline \multirow{2}{*}{ No } & & \multirow{2}{*}{ Protein Name } & \multicolumn{3}{|c|}{ Action } & \multirow[b]{2}{*}{ Catalysis } & \multirow{2}{*}{ Score } \\
\hline & & & Activation & Inhibition & Binding & & \\
\hline 1. & CYP51A1 & $\begin{array}{l}\text { cytochrome } \mathrm{P} 450, \text { family } 51 \text {, } \\
\text { subfamily A, polypeptide } 1\end{array}$ & & $\mathrm{~V}$ & $\mathrm{~V}$ & $\mathrm{~V}$ & 0,997 \\
\hline 2. & CYP3A4 & $\begin{array}{l}\text { cytochrome } \mathrm{P} 450 \text {, family } 3 \text {, } \\
\text { subfamily A, polypeptide } 4\end{array}$ & V & V & V & V & 0,992 \\
\hline 3. & $\mathrm{ABCB} 1$ & ATP-binding cassette, sub-family & & V & V & & 0,988 \\
\hline 4. & CYP2B6 & $\begin{array}{l}\text { cytochrome P450, family } 2 \text {, } \\
\text { subfamily B, polypeptide } 6\end{array}$ & V & V & V & V & 0,979 \\
\hline 5. & CYP3A5 & $\begin{array}{l}\text { cytochrome } \mathrm{P} 450 \text {, family } 3 \text {, } \\
\text { subfamily A, polypeptide } 5\end{array}$ & V & V & V & & 0,904 \\
\hline 6. & CYP3A7 & $\begin{array}{l}\text { Cytochrome P450, family } 3 \text {, } \\
\text { subfamily A, polypeptide } 7\end{array}$ & V & V & V & & 0,888 \\
\hline 7. & ALOX5 & arachidonate 5-lipoxygenase; & & V & & & 0,843 \\
\hline 8. & CYP1A1 & $\begin{array}{l}\text { cytochrome } \mathrm{P} 450 \text {, family } 1 \text {, } \\
\text { subfamily A, polypeptide } 1\end{array}$ & V & V & V & & 0,832 \\
\hline 9. & CYP24A1 & $\begin{array}{l}\text { cytochrome } \mathrm{P} 450 \text {, family } 24 \text {, } \\
\text { subfamily A, polypeptide } 1\end{array}$ & & V & V & & 0,832 \\
\hline 10. & CYP2C9 & $\begin{array}{l}\text { cytochrome } \mathrm{P} 450 \text {, family } 2 \text {, } \\
\text { subfamily C, polypeptide } 9\end{array}$ & & V & V & & 0,830 \\
\hline
\end{tabular}

Table 4 showed predicted functional partners of the active compound in the BFMEC with the potential of hepatotoxicity. Figure $3 \mathrm{~b}$ showed the interaction between proteins that were targeted by BFMEC compounds. There were interrelated interactions between CYP51A1, CYP2C9, CYP3A4, ABCB1, CYP2B6, CYP3A5, and CYP3A7. ALOX5 is interrelated to CYP2B6 and CYP2C9.

\section{DISCUSSION}

Hypertension is a major risk factor for cardiovascular disease. It's about one third of hypertension sufferers are undiagnosed, and of those diagnosed, about half do not use antihypertensive drugs. The World Health Organization (WHO) estimates that high blood pressure directly or indirectly causes the deaths of at least nine million people globally every year. ${ }^{7}$ Antihypertensives can be divided into two major groups, the first group are groups that directly or indirectly block the renin-angiotensin system (RAS), for example, ACE inhibitors, angiotensin receptor antagonists (ARA), direct renin inhibitors (DRI), and $\beta$-blockers. Although these drugs have several mechanisms of action, their dominant effect is to cause vasodilation. The second group of drugs works by increasing the excretion of water and sodium and reducing intravascular volume. This drug causing vasodilation via non-RAS pathways, for example, diuretics and calcium channel blockers (CCB). This second group action increases RAS activity through negative feedback. ${ }^{1}$

\section{Cantaloupe extraction and phytochemical testing}

Maceration with methanol solvent on 200 grams of cantaloupe powder simplicia produced 16.03 
grams of crude extract and 2.214 grams of n-butanol fraction. Phytochemical tests were carried out using the LC-MS method showed that there were 434 types of bioactive compounds (Figure 1). Butanol has more than two carbon atoms and has significant solubility in water ${ }^{8}$, shown in Figure 4.

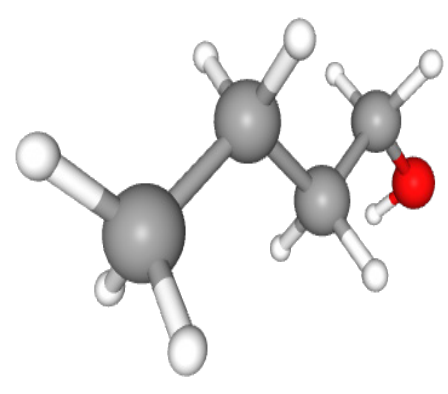

Figure 4. 3D Structure of n-butanol ${ }^{9}$

Butanol is used as a solvent because it can attract semi-polar organic compounds. Semi-polar organic compounds include flavonoids with a slightly lower polarity index below the polarity index of ethyl acetate (polarity index ethyl acetate $=4.3$ and n-butanol $=3.9$ ) due to the presence of functional groups attached to it or other compounds that have functional groups are polar. ${ }^{10}$

\section{Anti-hypertensive potential}

Based on the results of the analysis of antihypertensive potential on Way2Drug, there were 24 compounds had the potential as antihypertensive drugs in BFMEC marked with a value of $\mathrm{Pa}>0.3$ (data not shown). However, only 3 compounds (Table 1) displayed direct interaction with the target proteins (Table 2); amlodipine (2162), okadaic acid (446512), and terfenadine (5405), respectively.

Amlodipine has been widely used as 1,4-dihydropyridine calcium channel blockers (DHP-CCBs) as coadministrator with statins for hypercholesterolemia and hypertension. To reduce the myopathy risk, the FDA suggests taking amlodipine caused its ability to interact with CYP3A4 as well as CYP3A5. ${ }^{11}$ Other studies also mentioned the amlodipine impact among high-risk blood pressure African-American patients with CYP3A4 genotype. ${ }^{12}$ Amlodipine stabilizes voltage-gated L-type calcium channels in an inactive conformation, thus, prevents calcium-dependent myocyte contraction and vasoconstriction. ${ }^{13}$ Based on our results, amlodipine interacted directly not only with CYP3A4, but also to REN, and CACNA1C (Figure 2a). Apparently,
REN produces angiotensin I from angiotensinogen in plasma. CYP3A4 involve in NADPH-dependent electron transport pathway in the liver microsomes. It has previously been stated that the renin gene is associated with critical hypertension in a number of ethnic groups. ${ }^{14}$ A previous study mentioned the effect of amlodipine on REN gene. It was emphasized that blocking of amlodipine calcium channels promotes renin secretion and in vivo expression of the renin gene. These stimulatory effects are almost additive to improvements in renin secretion that arise after renal perfusion pressure decreases unilaterally. ${ }^{15}$ CACNA1C is a calcium channel, voltage-dependent, $\mathrm{L}$ type, alpha 1C subunit. Downregulation of CACNA1C may lead mitochondrial resilience and oxidative stress in the neuronal cells which is related to affective disorder. ${ }^{16,17}$

Okadaic acid (OA) is a specific inhibitor of fosfoserin. Okadaic acid interacted with PPP2R4, PPP1CC, and PPP2R1A (Figure 2), all three are phosphatases. Because of this, the function of these phosphatases in cells was observed using this class of molecules. When OA binds to the phosphatase protein(s), various proteins inside the infected cell are hyperphosphorylated, which in turn decreases sodium secretion regulation and solvent cell permeability. ${ }^{18,19}$ High sodium consumption and elevated blood pressure levels are correlated with water accumulation, increased systemic peripheral tolerance, improvements in endothelial function, changes in large elastic artery structure and function, changes in sympathetic response, and autonomic cardiovascular system neural regulation. ${ }^{20}$ While IGF1R, usually overexpresses in the event of cancer. ${ }^{21}$ Okadaic acid inhibited IGF1R (Figure 2a) which means it might be able to become an anticancer agent.

Terfenadine interacted with KCNH2, CYP3A4, CYP2D6, and HRH1. Terfenadine inhibits KCNH2 (Figure 2a) which functions to mediate the rapid activation component of delayed rectifying potassium current in the heart. Inhibition of this protein will interfere with calcium transportation. Terfenadine also inhibits HRH1, inhibition of this protein can inhibit nerve transmission mediation in the central nervous system. ${ }^{22}$

Table 2 showed predicted functional partners of the active compound in the BFMEC with the potential of anti-hypertensive. Figure $2 b$ showed the interaction between proteins that were targeted by BFMEC compounds. There were interrelated 
interactions between PPP2R1A, PPP2R4, PPP1CC, and CACNA1C. PPP2R1A, PPP2R4, and PPP1CC are a group of protein phosphatase. IGF1R showed positive interaction with CYP3A4. REN and HRH1 didn't show any interaction with other target proteins. In this predicted functional partners showed that $\mathrm{KCNH} 2$ interacted with CACNA1C, CYP2D6, and CYP3A4. There was a study found that defects in potassium channel $\mathrm{KCNH} 2$ caused numerous congenital and acquired cardiac disease including autosomal-dominant long QT syndrome 2 (LQT2). ${ }^{23}$

\section{Hepatotoxicity potential}

Based on the results of the analysis of hepatotoxicity potential on ProTox-II, there were 10 compounds in the BFMEC that showed hepatotoxic activity with $\mathrm{Pa}>0.3$ (data not shown). However, there were only 2 compounds that interacted directly with the target proteins; itraconazole (3793) and efavirenz (64139) (Table 3).

Some of the adverse effect caused by Itraconazole is inducing heart attack ${ }^{24}$, and other effects such as hypokalemia, aspartate aminotransferase elevation, alanine aminotransferase elevation, gastrointestinal disturbances, diarrhea and a skin rash with a high dose $>400 \mathrm{mg} /$ day. Itraconazole's mechanism of action triggering heart failure is unknown; however, there were no causes that could lead to heart failures such as asthma, cardiomyopathy and other potential factors in the patient. ${ }^{25}$ Based on the networking analysis, itraconazole acts as an inhibitor for CYP51A1, CYP24A1, CYP1A1, CYP3A4, ABCB1, and ALOX5 (Figure 3a). Itraconazole is one of the triazole antifungal agents which inhibit cytochrome P-450-dependent enzymes that affect the impairment of ergosterol synthesis. ${ }^{26}$

The CYP group is the Cytochrome P450 family, in liver microsomes, this enzyme is involved in the NADPH-dependent electron transport pathway. ${ }^{27}$ The inhibition of this enzyme by Itraconazole can cause the disruption of calcium homeostasis in cells. Itraconazole also inhibits the $\mathrm{ABCB} 1$ protein, an Energy-dependent efflux pump that is responsible for reducing the accumulation of drugs in multidrugresistant cells. Thus inhibition of this protein causes an increase in drug accumulation in multidrugresistant cells. ${ }^{28}$ Another protein that was inhibited by Itraconazole is ALOX5 (Figure 3). The presence of inhibition in ALOX5 can cause the disruption of the inflammatory process. ${ }^{29}$
Efavirenz interacted with itraconazole and 6 proteins; CYP3A7, CYP3A4, CYP1A1, CYP2C9, CYP3A5, and $\mathrm{CYP} 2 \mathrm{~B} 6$, respectively. Itraconazole interacted with efavirenz and 10 proteins; CYP51A1, ABCB1, ALOX5, CYP24A1, CYP3A7, CYP3A4, CYP1A1, CYP2C9, CYP3A5, and CYP2B6, respectively. These proteins are in the cytochrome $\mathrm{P} 450$ family, except ABCB1 and ALOX5. Efavirenz showed an interaction with CYP2B6 which was marked by a purple line which showed catalytic action with a score of 0.800 . As for the Itraconazole compound and other proteins, there was no significant interaction. It was reported that Efavirenz has neurotoxic effects..$^{30,31}$

Figure $3 \mathrm{~b}$ showed the interaction between target proteins in the hepatotoxicity mechanism. Table 4 showed predicted functional partners of the active compound in the BFMEC with the hepatotoxicity potential. This interaction involved cytochrome P450 family. Cytochrome P450 is classified as hemeprotein responsible in the drug metabolism and xenobiotic. ${ }^{32}$ Drugs with common pathway may involve in the drug-drug interaction ${ }^{33}$, however not all drugs have Cytochrome P450 activity. Drugs with Cytochrome P450 activity may be inhibitors, inducers, or substrates for a specific Cytochrome P450 enzymatic pathway, which may alter the metabolism of agents simultaneously administrated. Drugs that inhibit enzymatic pathway of Cytochrome P450 may cause increased concentration of other drugs metabolized by the same pathway and resulting in drug toxicity. ${ }^{32}$ In conclusion, the BFMEC may work in lowering blood pressure through the action mechanism of the amlodipine compound-like, which stabilizes voltage-gated L-type calcium channels in an inactive conformation, thus, prevents calcium-dependent myocyte contraction and vasoconstriction. The BFMEC may potentially hepatotoxic through the action mechanism of itraconazole which inhibits cytochrome P-450-dependent enzymes that affect the impairment of ergosterol synthesis and efavirenz which has neurotoxic effects.

\section{Acknowledgments}

This researcher would like to thank the Directorate General of Research and Development Strengthening (DGRDS) of the Ministry of Research, Technology, and the Higher Education of the Republic of Indonesia for funding this research $(037 / \mathrm{SP} 2 \mathrm{H} / \mathrm{LT} /$ K7/KM/2018). 


\section{REFERENCES}

1. Jackson R, Bellamy M. Antihypertensive drugs. Contin Educ Anaesth Crit Care Pain. 2015;15(6):2805. doi:10.1093/BJACEACCP/MKU061.

2. Xenobiotic - an overview / ScienceDirect Topics [Internet]. [Cited 2020 June 3]. Available from: https://www.sciencedirect.com/topics/immunologyand-microbiology/xenobiotic.

3. $\mathrm{Gu} \mathrm{X}$, Manautou JE. Molecular mechanisms underlying chemical liver injury. Expert Rev Mol Med. 2012;14:e4. doi:10.1017/S1462399411002110.

4. Elfahmi, Woerdenbag HJ, Kayser O. Jamu: Indonesian traditional herbal medicine towards rational phytopharmacological use. J Herb Med. 2014;4(2):51-73. doi:10.1016/j.hermed.2014.01.002.

5. Sulistyowati E, Hsu JH, Cheng YB, Chang FR, Chen YF, Yeh JL. Indonesian herbal medicine prevents hypertension-induced left ventricular hypertrophy by diminishing NADPH oxidase-dependent oxidative stress. Oncotarget. 2017;8(49):86784. doi:10.18632/ oncotarget.21424.

6. Yuan RQ, Qian L, Yun WJ, et al. Cucurbitacins extracted from Cucumis melo L. (CuEC) exert a hypotensive effect via regulating vascular tone. Hypertens Res. August 2019. doi:10.1038/s41440019-0258-y.

7. Kitt J, Fox R, Tucker KL, McManus RJ. New approaches in hypertension management: a review of current and developing technologies and their potential impact on hypertension care. Curr Hypertens Rep. 2019;21(6). doi:10.1007/s11906019-0949-4.

8. Atsumi S, Hanai T, Liao JC. Non-fermentative pathways for synthesis of branched-chain higher alcohols as biofuels. Nature. 2008;451(7174):86-89. doi:10.1038/nature 06450

9. 1-Butanol | C4H9OH - PubChem. [Cited 2020 June 3] Available from: https://pubchem.ncbi.nlm.nih. gov/compound/butanol.

10. Wikanta T, Gusmita D, Rahayu L, Marraskuranto E. Kajian awal bioaktivitas ekstrak etanol dan fraksinya dari spons callyspongia sp. terhadap sel lestari tumor HeLa. J Pascapanen dan Bioteknol Kelaut dan Perikan. 2012;7(1):1. doi:10.15578/jpbkp.v7i1.64. Indonesian.

11. Zhou YT, Yu LS, Zeng S, Huang YW, Xu HM, Zhou Q. Pharmacokinetic drug-drug interactions between 1,4-dihydropyridine calcium channel blockers and statins: factors determining interaction strength and relevant clinical risk management. Ther Clin Risk Manag. 2014;10(1):17-26. doi:10.2147/TCRM. S55512.

12. Bhatnagar V, Garcia EP, O'Connor DT, et al. CYP3A4 and CYP3A5 polymorphisms and blood pressure response to amlodipine among African-American men and women with early hypertensive renal disease and the AASK study investigators. Am J Nephrol. 2010;31(2):95-103. doi:10.1159/000258688.

13. Wagner L, Kenreigh C. Amlodipine. In: XPharm: the comprehensive pharmacology reference. Elsevier Inc.; 2007:1-5. doi:10.1016/B978-0080552323.61217-6.

14. Sun B, Williams JS, Pojoga L, et al. Renin gene polymorphism: Its relationship to hypertension, renin levels and vascular responses. JRAAS - J ReninAngiotensin-Aldosterone Syst. 2011;12(4):564-571. doi: $10.1177 / 1470320311405873$.

15. Schricker K, Hamann M, Macher A, Krämer BK, Kaissling B, Kurtz A. Effect of amlodipine on renin secretion and renin gene expression in rats. $\mathrm{Br} \mathrm{J}$ Pharmacol. 1996;119(4):744-750. doi:10.1111/j.1476-5381.1996.tb15735.x.

16. Bhat S, Dao DT, Terrillion CE, et al. CACNA1C (Ca $\mathrm{v} 1.2)$ in the pathophysiology of psychiatric disease. Prog Neurobiol. 2012;99(1):1-14. doi:10.1016/j. pneurobio.2012.06.001.

17. Michels S, Ganjam GK, Martins $\mathrm{H}$, et al. Downregulation of the psychiatric susceptibility gene Cacnalc promotes mitochondrial resilience to oxidative stress in neuronal cells. Cell Death Discov. 2018;4(1). doi:10.1038/s41420-018-0061-6.

18. Takai A, Murata M, Isobe M, Mieskes G, Yasumoto T. Inhibitory effect of okadaic acid derivatives on protein phosphatases. A study on structure-affinity relationship. Biochem J. 1992;284(2):539-544. doi:10.1042/bj2840539.

19. Dawson JF. Molecular mechanisms underlying inhibition of protein phosphatases by marine toxins. Front Biosci.1999;4(1-3):d646. doi:10.2741/dawson.

20. Grillo A, Salvi L, Coruzzi P, Salvi P, Parati G. Sodium intake and hypertension. Nutrients. 2019;11(9). doi:10.3390/nu11091970.

21. Solomon-Zemler R, Sarfstein R, Werner H. Nuclear insulin-like growth factor-1 receptor (IGF1R) displays proliferative and regulatory activities in nonmalignant cells. PLoS One. 2017;12(9). doi:10.1371/ journal.pone. 0185164 .

22. $\mathrm{Lu} \mathrm{C}$, Diehl SA, Noubade $\mathrm{R}$, et al. Endothelial histamine H1 receptor signaling reduces bloodbrain barrier permeability and susceptibility to autoimmune encephalomyelitis. Proc Natl Acad Sci U S A. 2010;107(44):18967-18972. doi:10.1073/ pnas. 1008816107 .

23. Arnaout R, Ferrer T, Tristani-Firouzi M, Stainier D, Chi N. Abstract 1062: Kenh2 mutations cause silent ventricle in zebrafish null model | Circulation. Circulation. 2006;114(II):196. [Cited 2020 June 4]. Available from: https://www.ahajournals.org/ doi/10.1161/circ.114.suppl_18.II_196.

24. Denolle T, Azizi M, Massart C, Zennaro MC. HTA sous itraconazole: une nouvelle cause d'HTA iatrogène. Ann Cardiol Angeiol (Paris). 2014;63(3):213-215. doi:10.1016/j.ancard.2014.05.007. 
25. Okuyan H, Altin C. Heart failure induced by itraconazole. Indian J Pharmacol. 2013;45(5):524525. doi:10.4103/0253-7613.117751.

26. Lass-Flörl C. Triazole antifungal agents in invasive fungal infections: a comparative review. Drugs. 2011;71(18):2405-2419. doi:10.2165/11596540000000000-00000.

27. Klinger W, Lupp A, Barth A, et al. Cytochrome P450 (P450) isoforms expression, P450 concentration, monooxygenase activities, reactive oxygen species formation, lipid peroxidation, and glutathione content in wild catch carp and tench liver--influence of a two weeks exposure to phenobarbital. Exp Toxicol Pathol. 2001;52(6):513-522. doi:10.1016/S09402993(01)80008-7.

28. Armada A, Martins C, Spengler G, et al. Fluorimetric methods for analysis of permeability, drug transport kinetics, and inhibition of the ABCB1 membrane transporter. Methods Mol Biol. 2016;1395:87-103. doi:10.1007/978-1-4939-3347-1_7.
29. Titos E, Ferré N, Lozano JJ, et al. Protection from hepatic lipid accumulation and inflammation by genetic ablation of 5-lipoxygenase. Prostaglandins Other Lipid Mediat. 2010;92(1-4):54-61. doi:10.1016/j.prostaglandins.2010.03.001.

30. Decloedt EH, Maartens G. Neuronal toxicity of efavirenz: a systematic review. Expert Opin Drug Saf. 2013;12(6):841-846. doi:10.1517/14740338.201 3.823396 .

31. Nazziwa R, Sekadde M, Kanyike F, Wobudeya E, Nabukeera-Barungi N. Efavirenz poisoning in a 12 year old HIV negative African boy. Pan Afr Med J. 2012;12:86. [Cited 2019 October 15]. Available from: http://www.ncbi.nlm.nih.gov/pubmed/23077707.

32. McDonnell, PharmD, BCOP AM, Dang, PharmD, BCPS CH. Basic review of the Cytochrome P450 System. J Adv Pract Oncol. 2013;4(4):263. doi:10.6004/jadpro.2013.4.4.7.

33. Nelson DR. The cytochrome P450 homepage. Hum Genomics. 2009;4(1):59-65. doi:10.1186/1479-73644-1-59. 